American Journal of Applied Sciences 6 (6): 1059-1066, 2009

ISSN 1546-9239

(C) 2009 Science Publications

\title{
Microbial Growth, Sensory Characteristic and pH as Potential Spoilage Indicators of Chinese Yellow Wet Noodles from Commercial Processing Plants
}

\author{
${ }^{1}$ Suwaibah Ghaffar, ${ }^{1,3}$ Abdulamir AS, ${ }^{1}$ Fatimah Abu Bakar, ${ }^{2}$ Roselina Karim and ${ }^{1}$ Nazamid Saari \\ ${ }^{1}$ Department of Food Science, ${ }^{2}$ Department of Food Technology, Faculty of Food Science and \\ Technology, University Putra Malaysia, 43400, Serdang, Selangor, Malaysia \\ ${ }^{3}$ Faculty of Medicine, Alnahrain University, Iraq
}

\begin{abstract}
Problem statement: This study was conducted to evaluate the potential use of microbial growth, sensory characteristic (odour) and $\mathrm{pH}$ as potential spoilage indicators of Chinese yellow wet noodles. Approach: Samples were collected from 3 commercial processing plants namely, Automated Processing (AP), Semi-automated Processing (SP) and Manual Processing (MP). The samples were kept at ambient temperature $\left(28 \pm 2{ }^{\circ} \mathrm{C}\right)$ and monitored microbiologically for ten days. Standard Plate Count (TPC) and Yeast and Mould Count (YMC) were determined using conventional spread plate methods. Sensory evaluation of noodles was carried out using Quantitative Descriptive Analysis (QDA). Results: Initial TPC for all samples were around $\log 3 \mathrm{CFU} / \mathrm{g}$ which significantly increased to around $\log 7 \mathrm{CFU} / \mathrm{g}$ towards the end of storage period. The same pattern was observed for YMC for all samples. Odour of AP, SP and MP samples began to deteriorate and samples became unacceptable to panelists on 3, 4 and 2 days of storage, respectively. Linear regression analyses between storage period and the various potential spoilage indicators demonstrated the strongest correlation for all samples between the storage time and odour $(r=0.81243-0.93856$ and $\mathrm{p}=<0.0001)$. Correlation between the storage period and TPC and YMC for AP samples were also strongly correlated $(r=0.80122-0.8573$ and $\mathrm{p}=<0.0001$ ). The correlation between storage time and TPC as well as YMC for both SP samples and MP samples were moderately correlated $(r=0.500-0.700$ and $p<0.05)$. Correlation between the storage time and $\mathrm{pH}$ were inversely correlated for all samples $(\mathrm{r}=-0.61439$ to -0.74931 and $\mathrm{p}=$ $<0.0001-0.0003$ ). Conclusion/Recommendation: Taken together, odor is the most suitable to be used as spoilage indicator for Chinese yellow wet noodles.
\end{abstract}

Key words: Chinese yellow wet noodles, microbial growth, sensory, spoilage indicators

\section{INTRODUCTION}

Asian noodles have been in existence for thousands of years. There are many different types of chilled, high moisture, wheat flour noodles available including fresh yellow alkaline noodles (Chinese yellow wet noodles), dry white salted noodles (mee sua) and raw noodles (wanton noodles), instant noodles, ramen and udon noodle ${ }^{[1,2]}$. Amongst the noodle family, Chinese yellow wet noodles are the most popular in the South East Asia. It is characterized by the presence of sodium hydroxide, giving the noodles their characteristics yellowness, alkaline flavor, high $\mathrm{pH}$ and usually parboiled $^{[3,4]}$. However, the main problem faced is the short shelf life of noodles resulting in high levels of wastage in the industry and it may also be a potential source of food poisonings ${ }^{[5,6]}$. A negative factor of shelf life in tropical regions is the lack of refrigerated storage and maintenance of continuous cold chain during manufacture and distribution of Chinese yellow wet noodles ${ }^{[7,8]}$.

To the best of our knowledge there is invariably insignificant information in literature on the spoilage indicators of Chinese yellow wet noodles during storage. The current study is one of the first steps towards prolonging the shelf life of noodles before any new preservation methods are developed. This study was therefore, undertaken to determine the microbiological profile, odor characteristic and $\mathrm{pH}$ of Chinese yellow wet noodles from three commercial processing plants stored at ambient temperature $\left(28 \pm 2{ }^{\circ} \mathrm{C}\right)$ and their potential as spoilage indicators.

\section{MATERIALS AND METHOD}

Samples collection: Noodle samples were collected, on the day of production, from the three different types

Corresponding Author: Fatimah Abu Bakar, Department of Food Science, Faculty of Food Science and Technology, University Putra Malaysia, 43400 UPM, Serdang, Selangor, Malaysia 
of processing plants in the Klang Valley which were Automated Processing samples (AP samples), Semi automated Processing samples (SP samples) and Manual Processing samples (MP samples). Samples were placed in a Styrofoam box and transported to the laboratory where they were stored at ambient temperature $\left(28 \pm 2{ }^{\circ} \mathrm{C}\right)$ until analyzed. The experiment was repeated three times.

AP samples were collected from fully automated processing plants. All of the procedures involved in the process of making noodles such as mixing of ingredients, sheeting, compounding, cutting, boiling, draining, oiling and packaging were done automatically.

SP samples were collected from semi-automated processing plants. Mixing of ingredients, sheeting, compounding, cutting, boiling and draining were done automatically but oiling and packaging were done manually by operators.

MP samples were collected from manual processing plants. Although mixing of ingredients, sheeting, compounding and cutting used machinery but they were manually operated. Noodles were manually cooked in the wok and allowed to cool on a bamboo tray before being oiled and packaged by operators.

Microbiological analysis: Samples were analyzed daily for ten continuous days. A 25-g sample was homogenized in $225 \mathrm{~mL}$ of $0.1 \%$ peptone water (Oxide CM009) in a stomacher bag using a stomacher machine (Lab-blender 400, Seward Laboratory) for $60 \mathrm{sec}$. Serial dilutions were prepared using $0.1 \%$ peptone water and $100 \mu \mathrm{l}$ of appropriate dilution inoculated onto appropriate agar plate using the Automated Spiral Platter (WASP 2-Don Whitley Scientific). TPC was determined using Plate Count Agar (Merck-1.05459) incubated at $35^{\circ} \mathrm{C}$ for $48 \mathrm{~h}$ whilst YMC was determined using Potato Dextrose Agar (Oxide CM0139) incubated at $30^{\circ} \mathrm{C}$ for 72 hours. Colonies were counted using the Automated Colony Counter (Whitley aCOLyte, Synbiosis Beacon House) connected to the Acolyte software. Analysis was conducted in duplicates.

Determination of pH: A 10-g sample was homogenized in $90 \mathrm{~mL}$ of distilled water in a stomacher bag using a stomacher machine (Lab-blender 400, Seward Laboratory) for $60 \mathrm{sec}$. The $\mathrm{pH}$ was measured using pH meter (Mettler Toledo-320). Five replicates from each of AP, SP and MP samples were analyzed.

Sensory evaluation: Sensory quality was evaluated using 10 trained panelists. Odour was used as a characteristic of acceptability. Scores were given from
1-10 whereby score 1 denotes excellent quality, score 5 denotes just acceptable quality and score 10 denotes completely deteriorated quality. The samples were considered unacceptable when the mean score was 5 and above.

Statistical analysis: Data obtained were analyzed using the SAS software version 6.12 (Statistical Analysis System) Analysis of Variances (ANOVA) was conducted at 95\% confidence level and Duncan's t-test was used for separation of means. Linear regression was used to establish statistical relationship between storage days and various potential spoilage indicators (TPC, YMC, odour characteristic and $\mathrm{pH}$ ). Pearson's correlation coefficient (r) and level of significance (p) were calculated for each sample. Relationship with $r$ $>0.700$ and $\mathrm{p}<0.05$ were considered strongly correlated, relationship with $r=0.500-0.700$ and $\mathrm{p}<0.05$ were considered moderately correlated and relationship with $\mathrm{r}<0.500$ and $\mathrm{p}>0.05$ were considered poorly correlated.

\section{RESULTS}

Microbiological quality of noodle samples: Changes in TPC of Chinese yellow wet noodles stored at ambient temperature $\left(28 \pm 2{ }^{\circ} \mathrm{C}\right)$ for 10 days are shown in (Table 1). Initial TPC of AP, SP and MP samples were from $\log 3.5 \mathrm{CFU} / \mathrm{g}, \log 3.8 \mathrm{CFU} / \mathrm{g}$ and $\log 3.6$ $\mathrm{CFU} / \mathrm{g}$, respectively. There were significant $(\mathrm{p}<0.05)$ increase in TPC for all samples during the 10 days storage and were around $\log 7 \mathrm{CFU} / g$ towards the end of storage period.

It is also shown in (Table 1) the changes in YMC of Chinese yellow wet noodles during 10 days of storage at ambient temperature $\left(28 \pm 2{ }^{\circ} \mathrm{C}\right)$. Initial YMC were at $\log 2.79 \mathrm{CFU} / \mathrm{g}, \log 3.47 \mathrm{CFU} / \mathrm{g}$ and $\log 3.28$ $\mathrm{CFU} / \mathrm{g}$ for AP, SP and MP samples, respectively. Counts for all samples significantly $(p<0.05)$ increased to around $\log 7 \mathrm{CFU} / \mathrm{g}$ at the end of storage.

Odour characteristic of noodle samples: Development of odour in Chinese yellow noodles stored at ambient temperature $\left(28 \pm 2^{\circ} \mathrm{C}\right)$ for 10 days are shown in (Table 2).

Samples were scored from 1 (extremely fresh) to 10 (completely deteriorated). Score 5 and above were considered unacceptable to the panelist. The average odour scores for AP samples significantly $(\mathrm{P}<0.05)$ increased from an initial value of 1.37-7.87 on the last day of storage. Samples were unacceptable to panelist after 3 days of storage. 
Am. J. Applied Sci., 6 (6): 1059-1066, 2009

Table 1: TPC of Chinese yellow wet noodles during storage at room temperature

\begin{tabular}{|c|c|c|c|c|}
\hline \multirow{2}{*}{$\begin{array}{l}\text { Storage } \\
\text { time(day) }\end{array}$} & \multirow{2}{*}{$\begin{array}{l}\text { Microbial } \\
\text { analysis }\end{array}$} & \multicolumn{3}{|c|}{ Processing procedures } \\
\hline & & Automated & Semi automated & Manual \\
\hline 0 & TPC & $3.54^{\mathrm{aD}} \pm 0.24$ & $3.80^{\mathrm{aC}} \pm 0.22$ & $3.66^{\mathrm{aB}} \pm 0.45$ \\
\hline 1 & & $3.94^{\mathrm{aCD}} \pm 0.13$ & $4.22^{\mathrm{aBC}} \pm 0.14$ & $4.75^{\mathrm{aAB}} \pm 0.83$ \\
\hline 2 & & $4.83^{\mathrm{aBC}} \pm 0.16$ & $5.87^{\mathrm{aABC}} \pm 1.09$ & $6.15^{\mathrm{aAB}} \pm 1.23$ \\
\hline 3 & & $5.62^{\mathrm{aB}} \pm 0.55$ & $6.25^{\mathrm{aABC}_{ \pm 1.22}}$ & $6.40^{\mathrm{aAB}} \pm 1.17$ \\
\hline 4 & & $7.37^{\mathrm{aA}} \pm 0.47$ & $6.58^{\mathrm{aAB}} \pm 1.17$ & $6.69^{\mathrm{aAB}} \pm 1.25$ \\
\hline 5 & & $7.78^{\mathrm{aA}} \pm 0.38$ & $6.78^{\mathrm{aAB}} \pm 1.06$ & $7.01^{\mathrm{aA}} \pm 1.34$ \\
\hline 6 & & $7.79^{\mathrm{aA}} \pm 0.35$ & $7.30^{\mathrm{aA}} \pm 0.99$ & $7.26^{\mathrm{aA}} \pm 1.04$ \\
\hline 7 & & $7.82^{\mathrm{aA}} \pm 0.15$ & $7.68^{\mathrm{aA}} \pm 0.69$ & $7.56^{\mathrm{aA}} \pm 0.76$ \\
\hline 8 & & $7.49^{\mathrm{aA}} \pm 0.21$ & $8.08^{\mathrm{aA}} \pm 0.26$ & $7.48^{\mathrm{aA}} \pm 0.73$ \\
\hline 9 & & $7.63^{\mathrm{aA}} \pm 0.07$ & $7.50^{\mathrm{aA}} \pm 0.33$ & $7.45^{\mathrm{aA}} \pm 0.46$ \\
\hline 0 & YMC & $2.79^{\mathrm{Ae}} \pm 0.10$ & $3.47^{\mathrm{aC}} \pm 0.25$ & $3.28^{\mathrm{aC}} \pm 0.16$ \\
\hline 1 & & $3.29^{\mathrm{aD}} \pm 0.20$ & $3.92^{\mathrm{aBC}_{ \pm 0}}$ & $4.12^{\mathrm{aBC}} \pm 0.73$ \\
\hline 2 & & $4.05^{\mathrm{aCDE}} \pm 0.47$ & $5.24^{\mathrm{aABC}} \pm 1.07$ & $5.30^{\mathrm{aABC}} \pm 1.11$ \\
\hline 3 & & $5.09^{\mathrm{aBCDE}} \pm 0.95$ & $5.73^{\mathrm{aABC}_{ \pm 1.14}}$ & $5.72^{\mathrm{aABC}} \pm 1.14$ \\
\hline 4 & & $5.57^{\mathrm{aABCD}_{ \pm 1.01}}$ & $5.81^{\mathrm{aABC}_{ \pm 1.29}}$ & $6.20^{\mathrm{aAB}} \pm 1.02$ \\
\hline 5 & & $5.95^{\mathrm{aABC}_{ \pm} \pm 1.05}$ & $6.05^{\mathrm{aABC}} \pm 1.33$ & $6.28^{\mathrm{aAB}} \pm 1.24$ \\
\hline 6 & & $6.40^{\mathrm{aABC}} \pm 1.12$ & $6.59^{\mathrm{aAB}} \pm 0.89$ & $6.93^{\mathrm{aAB}} \pm 0.94$ \\
\hline 7 & & $7.45^{\mathrm{aAB}} \pm 0.32$ & $6.59^{\mathrm{aAB}} \pm 0.89$ & $7.32^{\mathrm{aA}} \pm 0.41$ \\
\hline 8 & & $7.57^{\mathrm{aAB}_{ \pm 0}} \pm 0.32$ & $7.59^{\mathrm{aA}} \pm 0.48$ & $7.31^{\mathrm{aA}} \pm 0.73$ \\
\hline 9 & & $6.77^{\mathrm{aA}} \pm 0.71$ & $7.63^{\mathrm{aA}} \pm 0.47$ & $7.36^{\mathrm{aA}} \pm 0.75$ \\
\hline
\end{tabular}

${ }^{1}$ Means with different small letter superscripts within the same column are significantly different at $p \leq 0.05$

${ }^{2}$ Means with different capital letter superscripts within the same rows are significantly different at $\mathrm{p} \leq 0.05$

Table 2: Sensory scores (odour) of Chinese yellow wet noodles during storage at room temperature

\begin{tabular}{lllc}
\hline $\begin{array}{l}\text { Storage time } \\
\text { (day) }\end{array}$ & AP samples & & \\
& SP samples & 1,2 & MP samples \\
\hline 0 & $1.37^{\mathrm{Eb}} \pm 0.03$ & $1.77^{\mathrm{Da}} \pm 0.06$ & $2.20^{\mathrm{Eab}} \pm 0.03$ \\
1 & $2.90^{\mathrm{Da}} \pm 0.05$ & $3.70^{\mathrm{Cda}} \pm 0.51$ & $4.57^{\mathrm{Da}} \pm 1.07$ \\
2 & $3.37^{\mathrm{Dc}} \pm 0.34$ & $4.27^{\mathrm{CDb}} \pm 0.13$ & $6.90^{\mathrm{Ca}} \pm 0.20$ \\
3 & $4.03^{\mathrm{CDb}} \pm 0.35$ & $4.90^{\mathrm{ABC}} \pm 0.30$ & $7.30^{\mathrm{BCa}} \pm 0.46$ \\
4 & $5.10^{\mathrm{BCb}} \pm 0.75$ & $4.83^{\mathrm{BCb}} \pm 0.39$ & $7.80^{\mathrm{ABCa}} \pm 0.46$ \\
5 & $5.10^{\mathrm{BCa}} \pm 0.52$ & $5.60^{\mathrm{ABCa}} \pm 1.31$ & $7.80^{\mathrm{ABC}} \pm 0.32$ \\
6 & $6.57^{\mathrm{Aba}} \pm 0.32$ & $7.10^{\mathrm{Aba}} \pm 1.21$ & $8.53^{\mathrm{Aba}} \pm 0.12$ \\
7 & $6.97^{\mathrm{Aa}} \pm 0.72$ & $7.33^{\mathrm{Aba}} \pm 1.15$ & $8.53^{\mathrm{Aba}} \pm 0.08$ \\
8 & $7.86^{\mathrm{Aa}} \pm 0.64$ & $7.53^{\mathrm{Aba}} \pm 1.03$ & $8.67^{\mathrm{Aa}} \pm 0.12$ \\
9 & $7.87^{\mathrm{Aa}} \pm 0.52$ & $7.67^{\mathrm{Aa}} \pm 0.98$ & $8.93^{\mathrm{Aa}} \pm 0.03$ \\
\hline
\end{tabular}

${ }^{1}$ Means with different small letter superscripts within the same column are significantly different at $\mathrm{p} \leq 0.05$

${ }^{2}$ Means with different capital letter superscripts within the same rows are significantly different at $\mathrm{p} \leq 0.05$

Initial sensory score (odour) for SP samples were 1.77 and significantly $(\mathrm{p}<0.05)$ increased to around 7.00 at the end of storage. SP samples were unacceptable to panelist after 4 days of storage.

Odor scores of MP samples increased significantly $(\mathrm{p}<0.05)$ from $1.77-4.57$ after 2 days of storage and became unacceptable to panelists thereafter. Scores
Table 3: $\mathrm{pH}$ of Chinese yellow wet noodles during storage at room temperature

Storage time

\begin{tabular}{|c|c|c|c|}
\hline (day) & AP samples ${ }^{1,2}$ & SP samples 1,2 & MP samples ${ }^{1,2}$ \\
\hline$\overline{0}$ & $10.98^{\mathrm{Aa}} \pm 0.05$ & $10.21^{\mathrm{bA}} \pm 0.18$ & $10.68^{\mathrm{abA}} \pm 0.25$ \\
\hline 1 & $10.74^{\mathrm{aA}} \pm 0.17$ & $10.43^{\mathrm{aAB}} \pm 0.22$ & $9.27^{\mathrm{aAB}} \pm 0.76$ \\
\hline 2 & $10.52^{\mathrm{aA}} \pm 0.23$ & $9.67^{\mathrm{abAB}} \pm 0.59$ & $8.31^{\mathrm{bBC}} \pm 0.52$ \\
\hline 3 & $10.76^{\mathrm{aA}} \pm 0.16$ & $9.91^{\mathrm{aAB}} \pm 0.52$ & $7.51^{\mathrm{bC}} \pm 0.63$ \\
\hline 4 & $9.55^{\mathrm{aAB}} \pm 1.25$ & $9.47^{\mathrm{aAB}} \pm 0.64$ & $7.24^{\mathrm{aC}} \pm 0.69$ \\
\hline 5 & $9.95^{\mathrm{aAB}} \pm 0.78$ & $8.46^{\mathrm{aAB}} \pm 1.06$ & $7.26^{\mathrm{aC}} \pm 0.40$ \\
\hline 6 & $9.24^{\mathrm{aAB}} \pm 1.00$ & $8.19^{\mathrm{aAB}} \pm 1.18$ & $7.11^{\mathrm{aC}} \pm 0.45$ \\
\hline 7 & $8.98^{\mathrm{aAB}} \pm 1.20$ & $7.96^{\mathrm{aAB}} \pm 1.37$ & $7.03^{\mathrm{aC}} \pm 0.61$ \\
\hline 8 & $8.51^{\mathrm{aAB}} \pm 1.07$ & $7.98^{\mathrm{aAB}} \pm 1.36$ & $6.74^{\mathrm{aC}} \pm 0.55$ \\
\hline 9 & $7.41^{\mathrm{aB}} \pm 1.09$ & $7.29^{\mathrm{aB}} \pm 1.32$ & $6.54^{\mathrm{aC}} \pm 0.188$ \\
\hline
\end{tabular}

${ }^{1}$ Means with different small letter superscripts within the same column are significantly different at $p \leq 0.05$

${ }^{2}$ Means with different capital letter superscripts within the same rows are significantly different at $\mathrm{p} \leq 0.05$

increased significantly $(\mathrm{p}<0.05)$ from 6.90 on day 2 8.93 on the last day of storage.

Changes of pH: Changes of $\mathrm{pH}$ in Chinese yellow noodles stored at ambient temperature $\left(28 \pm 2{ }^{\circ} \mathrm{C}\right)$ for 10 days are shown in (Table 3 ). The $\mathrm{pH}$ for all samples decreased from around $\mathrm{pH}$ 10-7 during storage. Initially, there were no significant differences between all the samples. From day 1-2, pH of AP samples were significantly $(\mathrm{p}<0.05)$ higher compared to $\mathrm{pH}$ of $\mathrm{SP}$ and MP samples. There were significant $(\mathrm{p}<0.05)$ differences among all the samples on day 4. $\mathrm{pH}$ of AP and SP samples were significantly higher than MP samples throughout the storage period. $\mathrm{pH}$ of $\mathrm{AP}$ samples decreased from 10.97-7.41 during storage. Initial pH of SP samples were 10.21 but decreased to 7.29 on last day of storage. $\mathrm{pH}$ of SP samples dropped from $\mathrm{pH} 10.67$ to $\mathrm{pH} 6.53$.

Linear regression analyses: The data shown in (Fig. 1-12) and (Table 4) summarizes the results of linear regression analyses between times of storage and the various potential spoilage indicators including microbial growth (TPC and YMC), $\mathrm{pH}$ and odour scores. The strongest correlation was between the time of storage and odour scores $(\mathrm{r}=0.93856$ and $\mathrm{p}=$ $<0.0001),(\mathrm{r}=0.81243$ and $\mathrm{p}=<0.0001)$ and $(\mathrm{r}=$ $0.83212 \mathrm{p}=<0.0001$ ) for AP, SP and MP samples, respectively. Also categorized as strongly correlated were between the storage time and TPC $(r=0.8573 \mathrm{p}=$ $<0.0001)$ and, storage time and $\mathrm{YMC}(0.80122 \mathrm{p}=$ $<0.0001)$ for AP samples. 
Am. J. Applied Sci., 6 (6): 1059-1066, 2009

Table 4: Linear regression analyses of the storage period of Chinese yellow wet noodles stored at room temperature vs various potential quality indicators (Microbial growth -TPC and YMC, $\mathrm{pH}$, and sensory scores-odour)

\begin{tabular}{|c|c|c|c|c|c|c|}
\hline \multirow[b]{2}{*}{$\begin{array}{l}\text { Quality indicator } \\
\text { during storage }\end{array}$} & \multicolumn{2}{|c|}{ AP samples } & \multicolumn{2}{|c|}{ SP samples } & \multicolumn{2}{|c|}{ MP samples } \\
\hline & $\begin{array}{l}\text { Correlation } \\
\text { coefficient }(\mathrm{r})\end{array}$ & $\begin{array}{l}\text { Level of } \\
\text { significance ( } \mathrm{p})\end{array}$ & $\begin{array}{l}\text { Correlation } \\
\text { coefficient ( } \mathrm{r} \text { ) }\end{array}$ & $\begin{array}{l}\text { Level of } \\
\text { significance (p) }\end{array}$ & $\begin{array}{l}\text { Correlation } \\
\text { coefficient ( } \mathrm{r} \text { ) }\end{array}$ & $\begin{array}{l}\text { Level of } \\
\text { significance ( } p)\end{array}$ \\
\hline Microbial growth (TPC) & 0.85730 & $<0.0010$ & 0.70361 & $<0.0010$ & 0.59501 & 0.0005 \\
\hline Microbial growth (YMC) & 0.80122 & $<0.0010$ & 0.68726 & $<0.0010$ & 0.69195 & $<0.0010$ \\
\hline Sensory scores (odour) & 0.93856 & $<0.0001$ & 0.81243 & $<0.0001$ & 0.83212 & $<0.0001$ \\
\hline $\mathrm{pH}$ & -0.64633 & 0.0001 & -0.61439 & 0.0003 & -0.74931 & $<0.0001$ \\
\hline
\end{tabular}

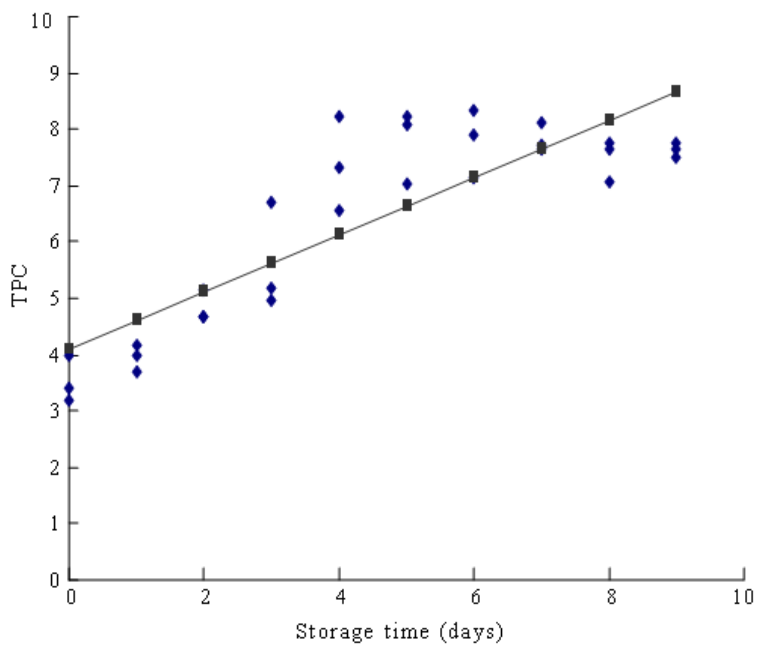

Fig. 1: Linear regression lines of Chinese yellow wet noodles (AP samples) during storage at room temperature vs potential quality indicator (TPC)

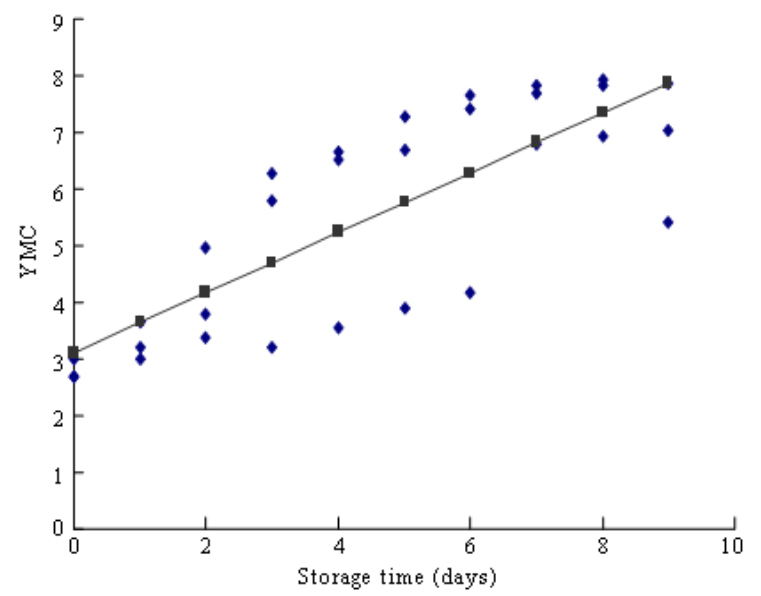

Fig. 2: Linear regression lines of Chinese yellow wet noodles (AP samples) during storage at room temperature vs potential quality indicator (YMC)

Correlation between storage time and TPC as well as YMC for both SP samples and MP samples were

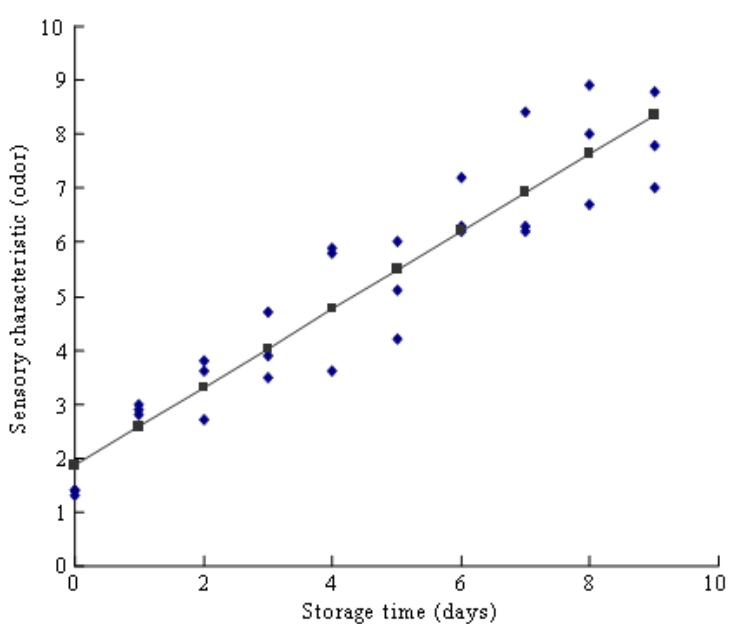

Fig. 3: Linear regression lines of Chinese yellow wet noodles (AP samples) during storage at room temperature vs. potential quality indicator (sensory characteristic-odour)

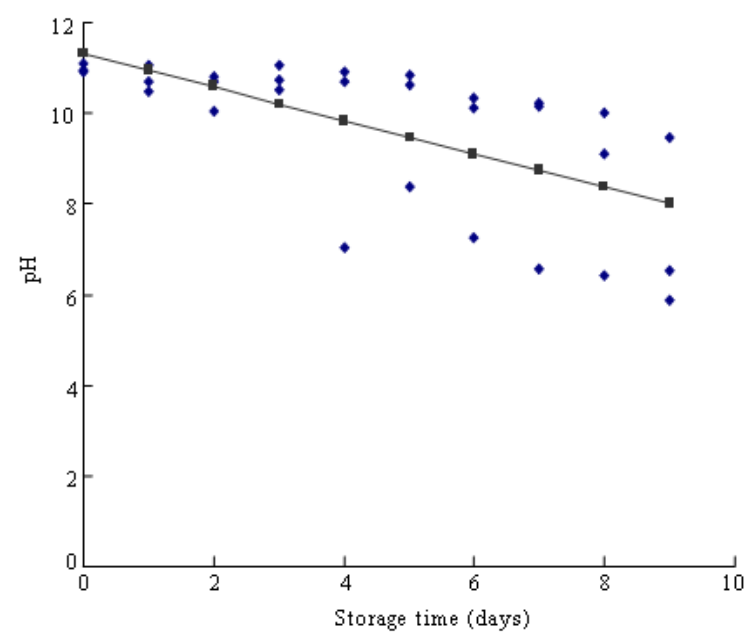

Fig. 4: Linear regression lines of Chinese yellow wet noodles (AP samples) during storage at room temperature vs. potential quality indicator $(\mathrm{pH})$

moderately correlated $(\mathrm{r}=0.500-0.700$ and $\mathrm{p}<0.05)$. Correlation between the storage time and $\mathrm{pH}$ were 


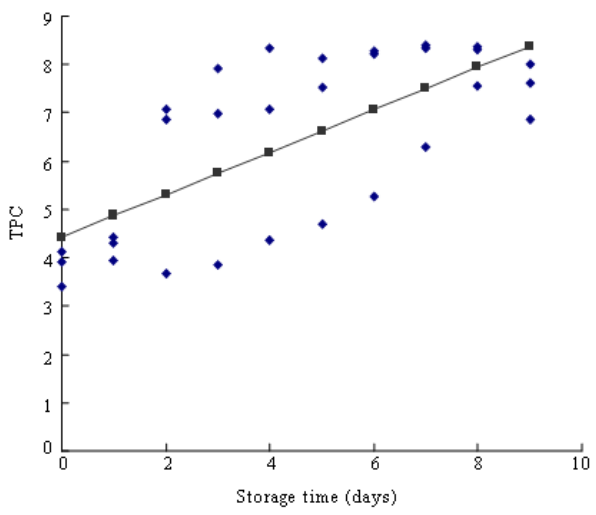

Fig. 5: Linear regression lines of Chinese yellow wet noodles (SP samples) during storage at room temperature vs. potential quality indicator (TPC)

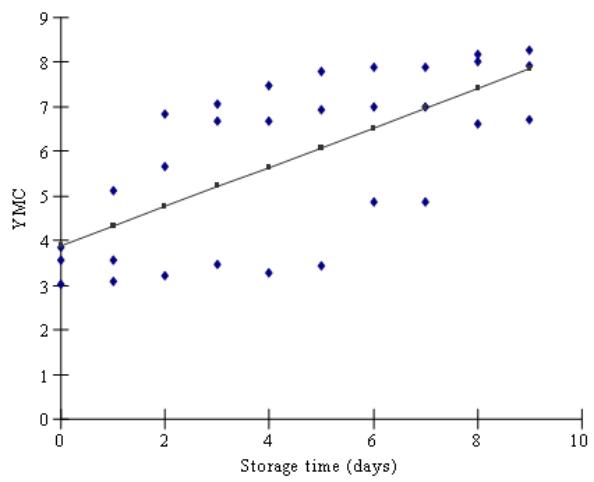

Fig. 6: Linear regression lines of Chinese yellow wet noodles (SP samples) during storage at room temperature vs. potential quality indicator (YMC)

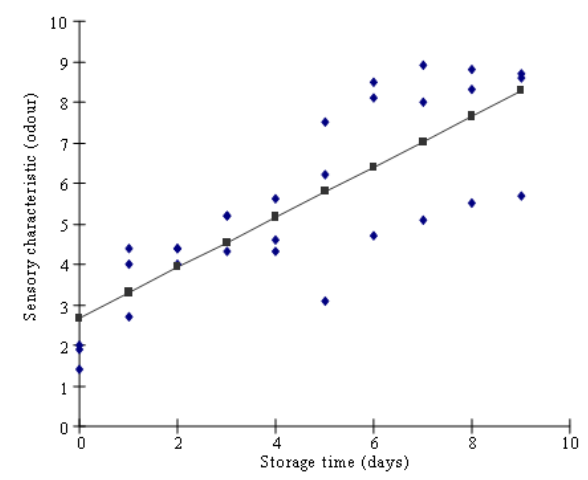

Fig. 7: Linear regression lines of Chinese yellow wet noodles (SP samples) during storage at room temperature vs. potential quality indicator (sensory characteristic-odour)

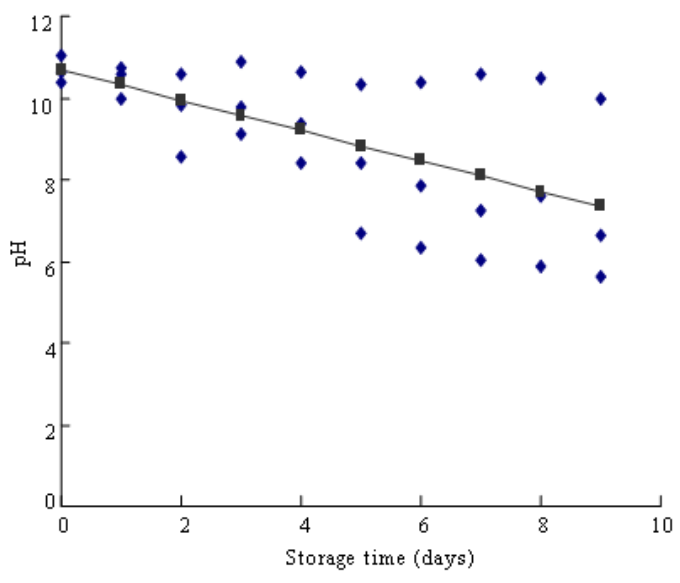

Fig. 8: Linear regression lines of Chinese yellow wet noodles (SP samples) during storage at room temperature vs. potential quality indicator $(\mathrm{pH})$

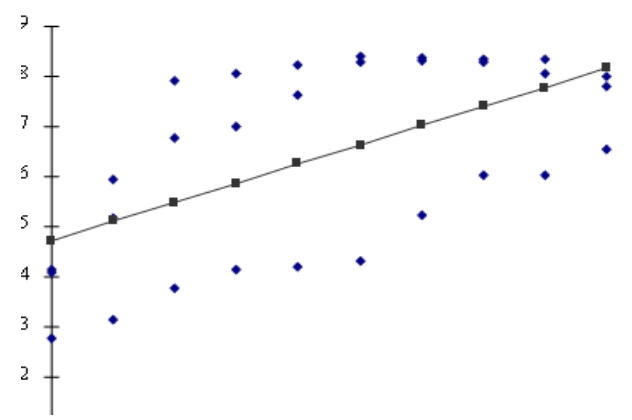

Fig. 9: Linear regression lines of Chinese yellow wet noodles (MP samples) during storage at room temperature vs. potential quality indicator (TPC)

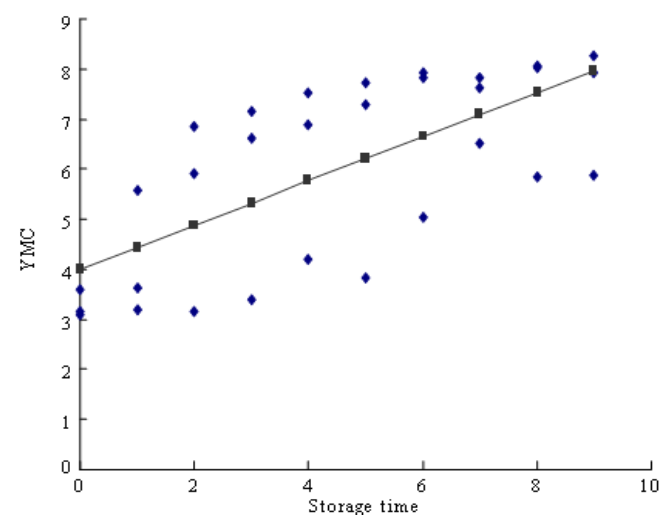

Fig. 10: Linear regression lines of Chinese yellow wet noodles (MP samples) during storage at room temperature vs. potential quality indicator (YMC) 


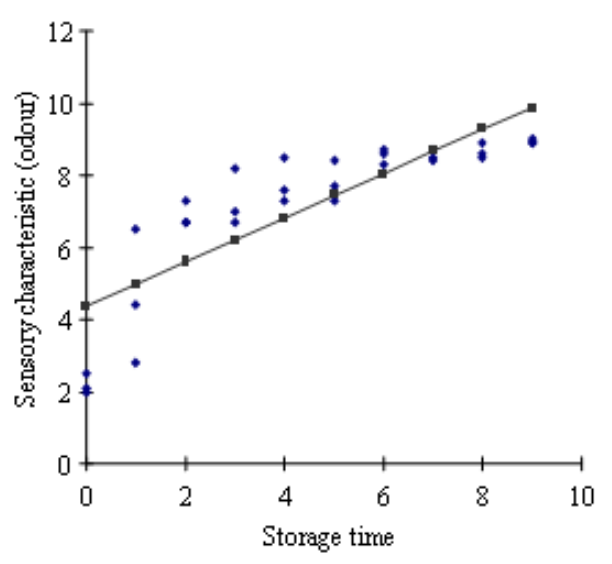

Fig. 11: Linear regression lines of Chinese yellow wet noodles (MP samples) during storage at room temperature vs. potential quality indicator (sensory characteristic-odour).

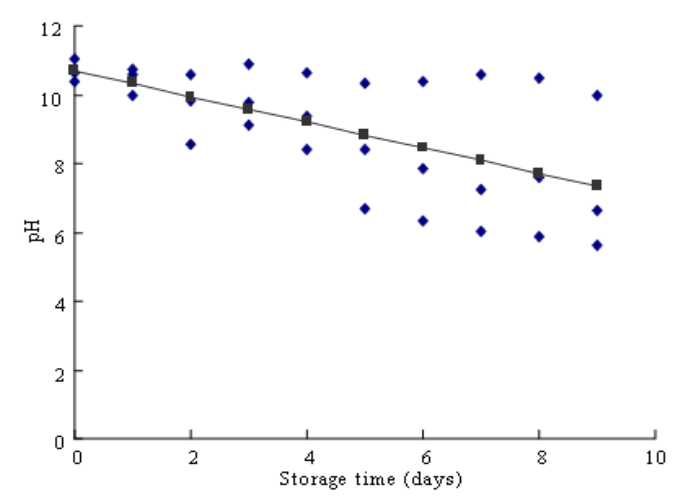

Fig. 12: Linear regression lines of Chinese yellow wet noodles (MP samples) during storage at room temperature vs. potential quality indicator $(\mathrm{pH})$

inversely correlated for all samples $(\mathrm{r}=-0.61439$ to 0.74931 and $\mathrm{p}=<0.0001$ to 0.0003 ).

\section{DISCUSSION}

Microbiological quality of noodle samples: The level of $10^{6} \mathrm{CFU} / \mathrm{g}$ in food can be considered as the cut off point between spoiled and unspoiled (level of insipient spoilage) and often forms the basis for criteria used to assess food quality ${ }^{[9]}$. In the present study, samples were considered spoiled when the level of TPC reached $\log 10^{6} \mathrm{CFU} / \mathrm{g}$. In general, results obtained in this study are similar to those previously reported by Jensen et $a l .{ }^{[10]}$ and $\mathrm{ANZFA}^{[11]}$ who observed TPC of $\log 5$ $\mathrm{CFU} / \mathrm{g}$ to $\log 8 \mathrm{CFU} / \mathrm{g}$ in fresh yellow alkaline noodles.
There was no significant difference among the three processing procedures when TPC and YMC were considered which means that processing method (automated, semi-automated or manual) does not relate to the microbial quality of noodles. Noodle samples with high TPC and YMC may have been processed under deficient hygiene and sanitation. Exposures to contamination are largely due to improper handling and packaging during processing regardless of its processing procedures. According to Kim et al. ${ }^{[12]}$ and Tutelian and Sukhanov ${ }^{[13]}$, improper handling and distribution of products may be detrimental to food safety and quality maintenance. Trovatelli ${ }^{[14]}$ reported a high percentage of contamination of fecal origin in pasta which was attributed to improper handling. The highest incidence of spoilage, especially rapid spoilage of processed food is caused by bacteria, followed by yeast and moulds ${ }^{[15]}$.

Noodles are usually partially cooked by boiling during processing and only require re-heating before consumption. They have a short shelf life and will deteriorate quickly if not stored under refrigeration ${ }^{[11]}$. Shelf life of noodles in Asia may only be a few days ${ }^{[10]}$. This study confirms the findings by Jensen et $a l .{ }^{[10]}$ and ANZFA $^{[11]}$ which recorded the TPC of AP, SP and MP samples reached level higher than $\log 6 \mathrm{CFU} / \mathrm{g}$ which is considered unacceptable after 3, 4, 2 days of storage, respectively.

The residues build up in processing plants and on equipment also constitute significant sources of microbiological contamination. Spore-forming species particularly, may reside in equipment, adversely affecting the quality of end products. Chinese yellow wet noodles manufacturers should pay more attention to the hygiene of their processing plants. Generally, the manufacturing of noodles in Malaysia lacks quality control especially with respect to raw materials, processing conditions and variables during noodles preparation.

Odour characteristic of noodle samples: Growth of microorganisms in foods causes spoilage by producing an unacceptable change in taste, odour, appearance, texture and combination of any of these factors ${ }^{[9]}$. The noodle samples were rejected by panelists because of its unacceptable odour. Odour was chosen in this study as a spoilage indicator for shelf life determination as it is the first characteristic perceived by panelists compared to other attributes.

Samples from SP have the most days of acceptability according to panelist followed by AP and 
MP samples. On the contrary, AP samples have the most days of acceptability according to when TPC reached $10^{6} \mathrm{CFU} / \mathrm{g}$ in noodle samples. This implies that off-odour detected by sensory panelist might not solely be of microbiological origin. Different formulations and ingredients for the different processing procedures might also play role in the development of off-odour. Manufacturing processes such as handling, processing and storage reflected the quality of the end products.

Spoilage of food was always associated with high numbers of microorganisms ${ }^{[16]}$, however on the contrary, manually processed noodle had relatively low numbers of bacteria when it became unacceptable to panelist. Spoilage of these samples might be largely due to biochemical processes which led to development of unacceptable off-odour. This further proves that the short shelf life of samples were due to biochemical deterioration leading to off-odour rather than increase in numbers of microorganisms. However, some microbial activities may also contribute to the deterioration process. Growth of microorganism in foods can cause textural changes associated with the breakdown of tissues ${ }^{[9,17]}$. Sensory characteristics could be the main spoilage indicator in noodles, as samples were considered unacceptable even though microbial population were not up to the level expected to cause spoilage. This could be a reliable method in determining the shelf life of wet noodle.

Changes of pH: $\mathrm{pH}$ changes in foods due to activity of microorganisms are common ${ }^{[18]}$. In food rich in both carbohydrates and proteins, microorganisms will usually utilize the carbohydrates, produce acids and reduce $\mathrm{pH}{ }^{[15]}$. The continuous drop of $\mathrm{pH}$ in noodle samples were suggesting that the type of spoilage was fermentative.

The initial $\mathrm{pH}$ for the noodle samples were in the alkaline range, which made it unfavorable for most microorganisms to grow. In general, bacteria grow fastest in $\mathrm{pH}$ range of 6.0-8.0 $0^{[16,19]}$. As the $\mathrm{pH}$ decreased towards neutral, TPC increased as most microorganisms were now able to grow well under this environment. Foods that have a high water activity and $\mathrm{pH}$ above 5.0 are likely to be spoiled by bacteria simply because under these conditions bacteria grow the fastest ${ }^{[9]}$. However, different processing plants use different formulations especially the kansui mixture which usually determined the initial $\mathrm{pH}$ of each samples. The lack of control especially the raw materials will definitely affect the initial $\mathrm{pH}$ and the drop of $\mathrm{pH}$ in noodle samples. Therefore, $\mathrm{pH}$ is not suitable to use as a spoilage indicator.
Linear regression analyses: The strong correlation between the storage time and odour scores indicates the suitability of this specific sensory characteristic as a spoilage indicator. Also categorized as strongly correlated were between the storage time and TPC and, storage time and YMC for AP samples. This indicates that bacterial count also could be a spoilage quality indicator but only suitable to be used for samples from automated processing plant. This indicates that bacterial count also could be a spoilage quality indicator but only suitable to be used for samples from automated processing plant.

\section{CONCLUSION}

Taken together, odor is the most suitable parameter to be used as spoilage indicator of Chinese yellow wet noodles. Bacteria count when used alone is not suitable as spoilage indicator. $\mathrm{pH}$ are not suitable as spoilage indicator due to the different kansui mixture used in formulating samples of Chinese yellow wet noodles which affects the initial $\mathrm{pH}$ of noodles. However these claims warrant further investigation into the spoilage indicators of Chinese yellow wet noodles.

\section{ACKNOWLEDGEMENT}

The researchers thank the technical staff of Federal Flour Mills for their help with this project and the Australian Wheat Board for the funds.

\section{REFERENCES}

1. Miskelly, D., 1998. Modern Noodle Based FoodsRaw Material Needs. In: Pacific People and their Food, Blakeney, A.B. and L.O. Brien, (Eds.). AACC, St Paul, pp: 123-142.

ISBN: 1891127039

2. Bui, L.T. and D.M. Small, 2007. Foliates in Asian noodles: III. Fortification, impact of processing and enhancement of foliate intakes. J. Food Sci., 72: C288-93. DOI: 10.1111/j.1750-3841.2007.00378.x

3. Kumagai, M., K. Karube, T. Sato, N. Ohisa, T. Amano, R. Kikuchi and N. Ogawa, 2002. A near infrared spectroscopic discrimination of noodle flours using a principal-component analysis coupled with chemical information. Anal. Sci., 18:1145-1150. DOI: 10.2116/analsci.18.1145.

4. Fuerst, E.P., J.V. Anderson and C.F. Morris, 2006. Delineating the role of polyphenol oxidase in the darkening of alkaline wheat noodles. J. Agric. Food Chem., 54: 2378-2384. http://www.wsu.edu/ wwql/reprints/Fuerst $\% 20$ et $\%$ 20al.2006.JAFC.54.2378.pdf. 
5. Tribe, I.G., H. Tsimogiannis, P. Mmolawa and D. Davos, 2001. An outbreak of Salmonella Typhimurium phage type 29 linked to a noodle restaurant in South Australia. Commun. Dis. Intell., 25: $72-76$.

http://www.ncbi.nlm.nih.gov/pubmed/11432532.

6. Hou, G., 2001. Oriental noodles. Adv. Food Nutr. Res., 43: 143-93. http://www.ncbi.nlm.nih.gov/pubmed/11285682

7. Xu, Y., C. Hall, 3rd, C. Wolf-Hall and F. Manthey. 2008. Fungistatic activity of flaxseed in potato dextrose agar and a fresh noodle system. Int. J. Food Microbiol., 121: 262-267. DOI: 10.1016/J.IJFOODMICRO.2007.11.005

8. Suzuki, H., Y. Yoshiike, K. Sugiyama, A. Hasegawa, S. Igimi, H. Toyofuku, S. Yamamoto and F. Kasug, 2007. Microbiological contamination of wheat, wheat flour and dough and fresh noodles made from wheat flour: A literature survey. Shokuhin Eiseigaku Zasshi, 48: J178-189. http://www.ncbi.nlm.nih.gov/pubmed/17515108

9. Garbutt, J., 1997. Essentials of Food Microbiology. Hodder Headline Group, London, pp: 124-129. ISBN: 0-340-67701-5

10. Jensen, N., A.D. Hocking, D. Miskelly and L.K. Berghofer, 2004. Microbiological safety of high moisture noodles: Marketplace survey of noodles sold in Australia. Food Sci. Austral., 56: 71-78.

http://www.cababstractsplus.org/abstracts/Abstract. aspx?AcNo=20043037681.

11. ANZFA, 2001. Food safety standards. Annual bulletin of food safety 2001-2002. http://www.foodstandards.gov.au/newsroom/public ations/annualreport/anzfaannualreport2001816.cfm

12. Kim, E.K., P.M. Scott and B.P. Lau, 2003. Hidden fumonisin in corn flakes. Food Addit Contam., 20: 161-169.

http://md1.csa.com/partners/viewrecord.php?requester=g s\&collection=ENV\&recid $=5683961 \& q=$ Hidden + fumoni sin+in+corn+flakes\&uid=\&setcookie=yes.
13. Tutel'ian, V.A. and B.P. Sukhanov. 2008. Food supplements: modern approaches to quality and safety. Vopr Pitan., 77: 4-15.

http://www.ncbi.nlm.nih.gov/pubmed/18839802

14. Trovatelli, L.D., A. Schiesser, S. Massa, D. Cesaroni and G. Poda. 1988. Microbiological quality of fresh pasta dumplings sold in Bologna and the surrounding district. Int. J. Food Microbiol., $7:$ 19-24. http://www.ncbi.nlm.nih.gov/pubmed/2908612.

15. Ray, B. 2001. Fundamental Food Microbiology. CRC Press, pp: 228-233. Second edition

16. Adams, M.R. and M.O. Moss, 2000. Food microbiology. Royal Society of Chemistry, pp: 5664.

17. Arvanitoyannis, I.S. and A. Traikou. 2005. A comprehensive review of the implementation of Hazard Analysis Critical Control Point (HACCP) to the production of flour and flour-based products. Crit. Rev. Food Sci. Nutr., 45: 327-370. DOI: 10.1080/10408390590967694.

18. Hakoda, A., H. Kasama, K. Sakaida, T. Suzuki and A. Yasui, 2006. Determination of the moisture content of instant noodles: interlaboratory study. J. AOAC Int., 89: 1585-1590. http://www.atyponlink.com/AOAC/doi/abs/10.5555/jaoi.89.6.1585.

19. Ral, J.P., C.R. Cavanagh, O. Larroque, A. Regina and M.K. Morell, 2008. Structural and molecular basis of starch viscosity in hexaploid wheat. J. Agric. Food Chem., 56: 4188-4197.

DOI: $10.1021 / \mathrm{jf} 800124 \mathrm{f}$ 